\title{
Simulation and Prediction of Groundwater Paths and Flow Vectors at Mosul City
}

\author{
Abdulghani A. Hasan \\ Thair M. Al-Taiee \\ Dams and water resources Research center Dams and water resources Research center \\ Mosul University \\ Mosul University
}

\begin{abstract}
High elevations of groundwater at Mosul city is a very big problem and may cause mass destructions to the environment, health and building foundations due to the closing of groundwater near ground surface. From field investigations for 43 large diameter shallow wells, the water elevations were measured 14 times through 7 months. Utilizing raster based GIS operations with automated parameter estimation (PEST), the conceptual model was build and converted to numerical model. The hydraulic conductivity values have been found after model calibration. The elevations, path lines and flow vectors maps were drawn from model results. Three sectors for groundwater elevations in the city have been defined and introduced to the water management agency for prompt decisions. The distributed finite-difference flow code (MODFLOW) selected in this study has approved to be a useful tool for creating a groundwater flow model for the study area. The results of the model can be used for the sewerage net design in Mosul city also for the planning of the agriculture and industrial projects.
\end{abstract}

Keywords: Groundwater; Mosul city; Environment; Modeling.

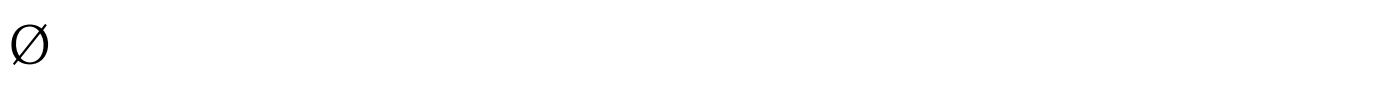 \\ Fô"

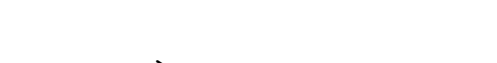

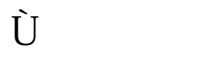

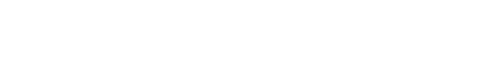

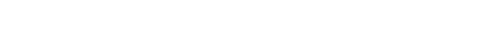

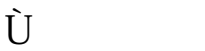

\section{rƯ TூKE}

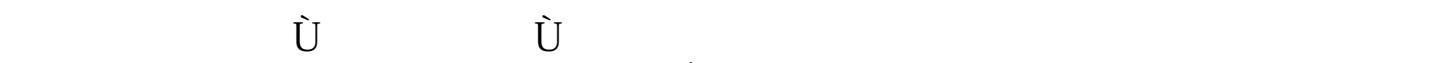
TuŬ ĐC 白 Đ) C '̌̉

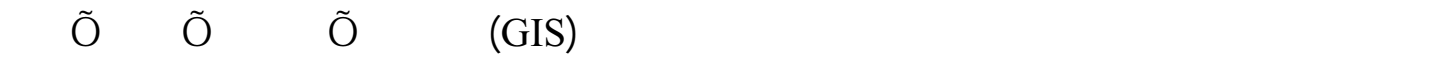
r̀»



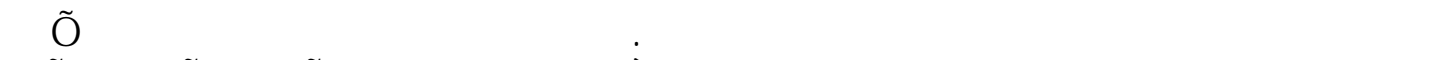

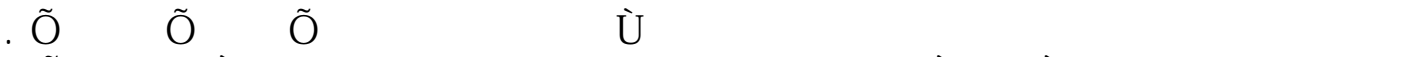

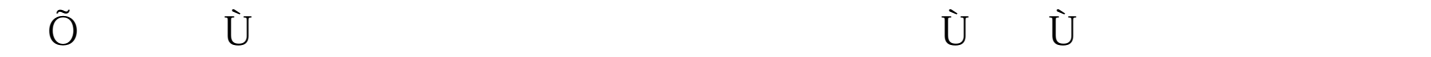

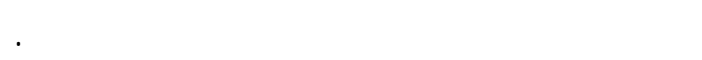




\section{INTRODUCTION}

Groundwater is considered one of the basic sources in many countries in the world to supply cities and urban places with water, for domestic, agricultural and industrial uses, due to unavailable surface water and lack in rainfall quantities. On the other hand, groundwater existence near ground surface may cause many engineering environmental problems in many places in the world, specially the urban places in the cities such as land flooding which may cause clogging in the storm and waste water network. This may lead to collect the rainfall water in addition to the released water quantities from homes and traditional shops especially during the strong rainfall storms. These surface water sumps may lead to environmental and health problems consequently may lead to negative effects on building foundations and structures. Recently this problem was appeared in Mosul City especially in the inner districts after the increasing in the construction and building processes. Mosul city is suffering in winter season at some places from the appearance of surface water collection due to weakly discharge especially after rainfall storms. Some places are suffering also from the land flooding which caused some environmental and health problems. From the observation and field survey in such places an increment in the groundwater elevations during winter season was observed.

Most of Mosul city is located topographically in a depression surrounded by hilly lands from the east and west slopping toward city centre and Tigris River (fig 1). This characteristic brought this city to delivers big quantities of surface runoff during rainfall flowing through number of main Wadies to Tigris River. A big quantity of these amounts of flowing water infiltrates and feeds the groundwater which may move in similarity with the surface water movement.[1]. This feeding process leads to the increasing in the groundwater levels and cause the land flooding in many places which already suffer from the ancient networks for waste and storm water due to the clogging process.

The aim of the present research is to study and evaluate the groundwater situation in Mosul city using computer simulation, starting with the prediction of conceptual model depending on some assumptions to get the final model. This model describes and simulates the groundwater movement in the city using field data such as groundwater elevation measurements in shallow hand dug wells existed in many places in the city. This study can be adopted in the future by other studies concerning the heavy waste water network design in addition to the possible uses in the planning of future industrial and agricultural projects.

\section{FIELD WORK}

The field work included studying the topographical maps for Mosul city used to calculate the area of the study region $\left(528 \mathrm{Km}^{2}\right)$. Surveying for 43 observation wells was conducted, (fig 1). Semi-monthly measurements for the groundwater elevations in those wells for about 7 months during the year 2001-2002 was collected (Table 1). 
The daily water supply to the city network from the pump stations was recorded as well. Many geological reports for the research area were studied, this aids in the relevant assumptions for the conceptual model in-addition to suggestion of number of soil permeability values and the groundwater aquifers which can be depended on the numerical model operation for describing the groundwater movements, elevations and flow directions in the city

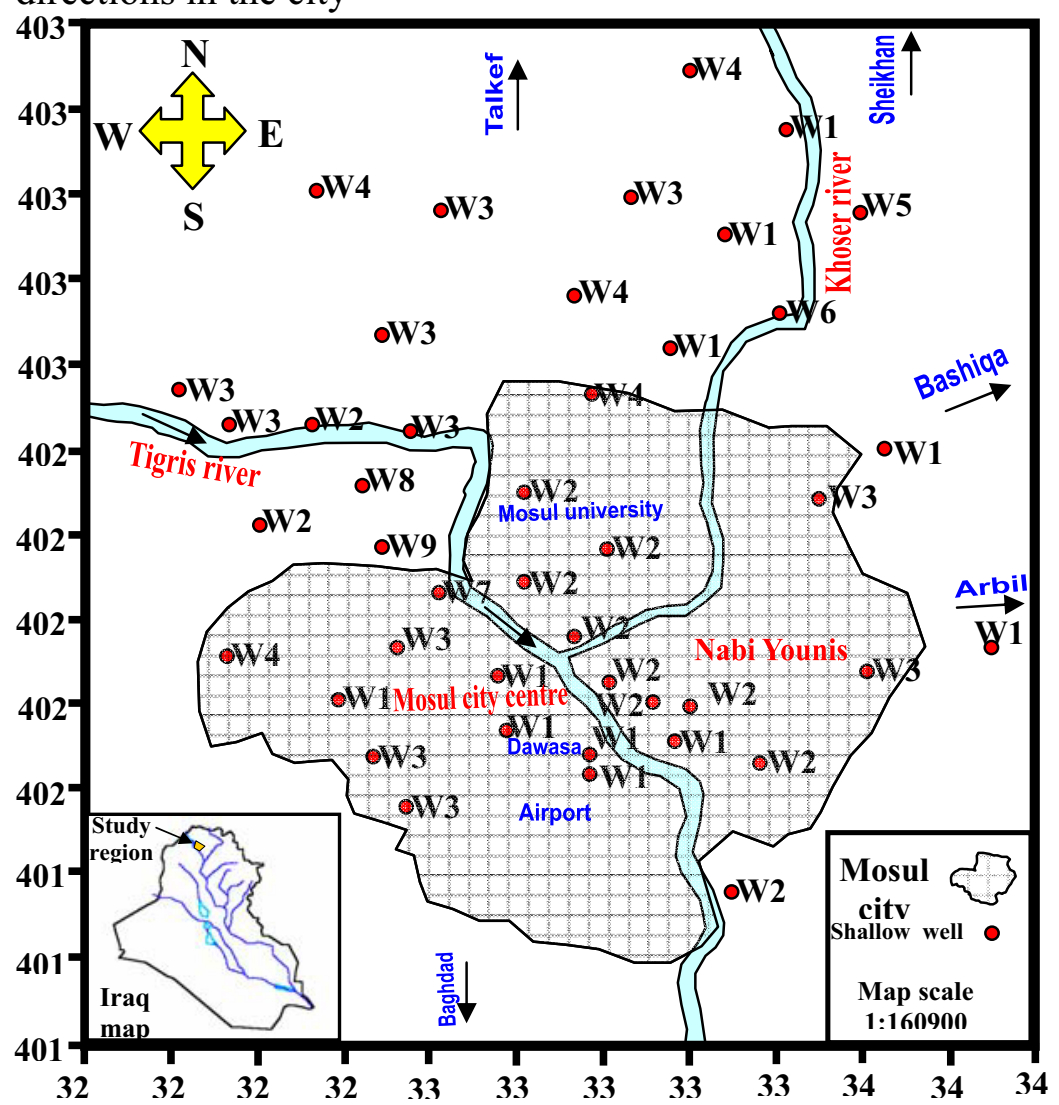

Figure 1. Regional map showing the study region boundary and observation well locations.

\section{GROUNDWATER FEEDING SOURCES AT MOSUL CITY}

Many assumptions and variables that may affect the groundwater elevations were studied and evaluated. The amount of leaked water from water supply network as a result of existing cracks in the network pipes was estimated to be $30 \%$ of all the pumped water quantities [1]. This is one of many reasons causes the increasing in the groundwater elevations in Mosul city. Another reason is the amount of released quantities of waste water from the houses, shops in-addition to the seepage water from septic tanks as a result of fissures in their beds. This leads to feed the groundwater which in-turn leads to variation in the soil properties and values of hydraulic conductivity. 
Table 1. Semi-monthly data for the groundwater elevations

\begin{tabular}{|c|c|c|c|c|c|c|c|c|c|c|c|}
\hline \multirow{2}{*}{$\begin{array}{l}\text { Well } \\
\text { No. }\end{array}$} & \multirow{2}{*}{$\begin{array}{c}\text { X-Axis } \\
\text { (m) }\end{array}$} & \multirow{2}{*}{$\begin{array}{c}\text { Y-Axis } \\
\text { (m) }\end{array}$} & \multirow{2}{*}{$\begin{array}{c}\text { G.Elv } \\
\text { (m) }\end{array}$} & \multicolumn{8}{|c|}{ Field water elevations in wells with time (m) } \\
\hline & & & & $\mathbf{0}$ & 32 & 61 & 89 & 121 & 153 & 182 & 215 \\
\hline$\overline{\mathbf{P 1}}$ & 923 & $\overline{151}$ & .33 & 243.2 & 243.6 & 43.88 & 243.68 & 243.63 & 243.4 & 43.33 & 242.23 \\
\hline P2 & 960 & 260 & & 234.1 & 34.55 & 34.85 & 234.62 & 34.57 & 234.74 & 34.65 & 234.75 \\
\hline P3 & 3620 & 21880 & 9.12 & 245.3 & 245.46 & 245.75 & 245.54 & 245.73 & 245.55 & 245.48 & 245.62 \\
\hline P4 & 25180 & 4024150 & 272.78 & 262.4 & 262.65 & 262.92 & 262.72 & 262.86 & 262.87 & 262.83 & 262.55 \\
\hline P5 & 39998 & 4034800 & 264.45 & 253.5 & 253.4 & 253.52 & 253.48 & 253.93 & 254.02 & 253.95 & 252.33 \\
\hline P6 & 8108 & 032307 & 53.32 & 242.32 & 242.52 & 242.22 & 242.59 & 242.77 & 242.22 & 242.17 & 242.05 \\
\hline P7 & 0056 & 42 & 8.32 & 212.03 & 212.05 & 212.2 & 212.13 & 212.46 & 212.42 & 212.35 & 211.75 \\
\hline P8 & 28360 & 4028241 & 22.31 & 214.1 & 214.54 & 214.79 & 214.61 & 214.57 & 213.99 & 213.96 & 213.06 \\
\hline P9 & 28806 & 4026814 & 223.12 & 217.72 & 218.1 & 218.28 & 218.18 & 218.15 & 218.06 & 218.02 & 217.4 \\
\hline P10 & 31763 & 4022471 & 226.31 & 223.26 & 223.49 & 223.81 & 223.56 & 223.72 & 223.85 & 223.76 & 223.66 \\
\hline P11 & 3713 & 17 & 20.45 & 215.4 & 215.98 & 216.15 & 216.06 & 215.83 & 216.47 & 216.4 & 215.93 \\
\hline P12 & 5577 & 403 & 252.53 & 242.13 & 242.67 & 242.22 & 242.74 & 242.58 & 242.23 & 242.17 & 242.85 \\
\hline P13 & 36773 & 4034151 & 261.62 & 254.5 & 254.54 & 254.48 & 254.62 & 254.93 & 254.87 & 254.8 & 254.06 \\
\hline P14 & 338339 & 4036680 & 268.73 & 257.6 & 257.77 & 257.82 & 257.84 & 258.07 & 258 & 257.92 & 257.1 \\
\hline P15 & 0414 & 402 & 5.14 & 245.2 & 245.3 & 245.52 & 245.38 & 245.63 & 244.59 & 244.52 & 244.32 \\
\hline P16 & 414 & 40 & 1.33 & 217.25 & 217.18 & 217.18 & 217.25 & 217.7 & 217.58 & 217.53 & 217.15 \\
\hline P17 & 33598 & 402 & 217.36 & 212.8 & 212.49 & 212.61 & 212.57 & 213.18 & 213.23 & 213.16 & 212.86 \\
\hline P18 & 335598 & 4022159 & 213.3 & 209.15 & 209.38 & 209.3 & 209.5 & 209.58 & 209.56 & 209.51 & 209.17 \\
\hline P19 & 77780 & 4023240 & 251.86 & 244.6 & 244.05 & 244.27 & 244.13 & 244.93 & 245.38 & 245.31 & 244.52 \\
\hline P20 & 703 & 85 & 3.13 & 207.18 & 207.87 & 207.85 & 207.96 & 207.61 & 208.41 & 208.35 & 208.2 \\
\hline $\mathbf{P 2 1}$ & 37635 & 81 & 222.78 & 214.2 & 214.63 & 214.92 & 214.71 & 214.7 & 215.11 & 215.04 & 214.82 \\
\hline $\mathbf{P 2 2}$ & 327117 & 4029622 & 218.57 & 211.5 & 211.4 & 211.46 & 211.45 & 211.93 & 211.79 & 211.72 & 211.04 \\
\hline $\mathbf{P 2 3}$ & 35964 & 4023038 & 219.69 & 212.3 & 212.83 & 212.92 & 212.91 & 212.77 & 212.59 & 212.55 & 212.75 \\
\hline $\mathbf{P 2 4}$ & 5094 & 4023178 & 213.5 & 210.05 & 209.96 & 210.08 & 210.02 & 210.53 & 210.85 & 210.78 & 210.38 \\
\hline $\mathbf{P 2 5}$ & 4031 & 92 & 1.8 & 208.16 & 208.49 & 208.61 & 208.57 & 208.59 & 208.78 & 208.7 & 208.19 \\
\hline $\mathbf{P 2 6}$ & 333326 & 4024599 & 213.5 & 210.22 & 210.11 & 210.2 & 210.19 & 210.57 & 210.38 & 210.31 & 210.15 \\
\hline $\mathbf{P 2 7}$ & 332105 & 4025970 & 215.72 & 208.33 & 208.21 & 208.26 & 208.29 & 208.76 & 208.4 & 208.35 & 208.07 \\
\hline $\mathbf{P} 28$ & 332047 & 4028107 & 218.33 & 210.15 & 210.18 & 210.93 & 210.28 & 210.4 & 210.43 & 210.36 & 209.77 \\
\hline $\mathbf{P 2 9}$ & 4140 & 026772 & 219.03 & 215.2 & 215.52 & 215.9 & 215.6 & 215.63 & 215.71 & 215.69 & 215.44 \\
\hline P30 & 329408 & 402 & 9.5 & 211.4 & 211.19 & 210.98 & 211.31 & 211.87 & 211.68 & 211.62 & 211.81 \\
\hline P31 & 324069 & 4030486 & 225.37 & 218.08 & 218.25 & 218.54 & 218.33 & 218.51 & 218.47 & 218.39 & 218.65 \\
\hline P32 & 325247 & 4029629 & 217.9 & 212.21 & 212.27 & 212.15 & 212.4 & 212.56 & 212.07 & 211.94 & 212.35 \\
\hline P33 & 328848 & 4031868 & 228.87 & 222.12 & 222.63 & 222.85 & 222.71 & 222.55 & 216.72 & 216.65 & 216.62 \\
\hline P34 & 329080 & 4024480 & 230.04 & 227.32 & 227.37 & 227.43 & 228.27 & 227.68 & 227.18 & 227.03 & 227.6 \\
\hline P35 & 329357 & 4020608 & 252.12 & 248.16 & 248.21 & 248.16 & 248.29 & 248.59 & 248.3 & 248.23 & 248.18 \\
\hline P36 & 340040 & 4023830 & 236.62 & 229.6 & 229.24 & 229.87 & 229.38 & 229.85 & 229.42 & 229.25 & 229.03 \\
\hline P37 & 339000 & 4027980 & 244.74 & 236.24 & 236.65 & 236.84 & 236.73 & 236.67 & 236.94 & 236.87 & 236.04 \\
\hline P38 & 334650 & 4035110 & 269.22 & 260.1 & 260.42 & 260.58 & 260.58 & 260.65 & 260.85 & 260.71 & 260.35 \\
\hline P39 & 330184 & 4034794 & 255.88 & 248.35 & 248.63 & 248.62 & 248.71 & 248.78 & 248.6 & 248.53 & 248.34 \\
\hline P40 & 333290 & 4032780 & 255.14 & 246.07 & 246.43 & 246.34 & 246.51 & 246.5 & 246.9 & 246.83 & 246.88 \\
\hline P41 & 333680 & 4030440 & 240.05 & 234.11 & 234.24 & 234.38 & 234.32 & 234.54 & 234.18 & 234.11 & 234.91 \\
\hline P42 & 335973 & 4038102 & 278.1 & 270.21 & 270.45 & 270.58 & 270.53 & 270.64 & 270.92 & 270.85 & 270.25 \\
\hline P43 & 327400 & 4035250 & 265.17 & 257.34 & 257.34 & 257.71 & 257.45 & 257.68 & 257.52 & 257.4 & 257.13 \\
\hline
\end{tabular}

\section{CELL BY CELL EQUATIONS}

For Numerical solution the flow continuity equation is valid, and for the Transient simulation the continuity equation is: 
$\mathbf{I}_{\text {in }}-\mathbf{Q}_{\text {out }}=\Delta \mathbf{S} / \Delta \mathbf{t}$

Where:

$\mathrm{I}_{\text {in }}$ : in flow $\left(\mathrm{L}^{3} / \mathrm{T}\right) \quad, \quad$ Qout: out flow $\left(\mathrm{L}^{3} / \mathrm{T}\right)$

$\Delta \mathrm{S}$ : change in storage,$\quad \Delta \mathrm{t}$ : change in time

for small aquifer volume equation (1) could be written:

Sum of subsurface flow + Flow from and to the surface $=$ change in storage

Using equation (1) in addition to Darcy equation (2) the result is equation (3).

$$
\begin{aligned}
& V=K \frac{\Delta h}{\Delta L} \\
& \frac{\partial}{\partial x}\left(T_{x} \frac{\partial h}{\partial x}\right)+\frac{\partial}{\partial y}\left(T_{y} \frac{\partial h}{\partial y}\right)+\left(T_{z} \frac{\partial h}{\partial z}\right)-q=S_{c} \frac{\partial h}{\partial t}
\end{aligned}
$$

Where:

$\left(T_{x}, T_{y}, T_{z}\right)$ : aquifer Transmisivity in directions $(X, Y, Z),\left(\mathrm{M}^{2} / \mathrm{T}\right)$

$\mathrm{S}_{\mathrm{c}}$ : Storage coefficient

q: Flow from and to the surface for small area $(\mathrm{L} / \mathrm{T})$

h: head (L)

t: time $(\mathrm{T})$

Equation (3) represent 3D transient flow for confined aquifer. It could be used for unconfined aquifer when the change in transmisivity is equal to the hydraulic conductivity multiplied by the saturated layer thickness $b(T=K . b)$. additionally this equation could be used for steady state flow after assigning the storage to be equal zero $(S=0)$. To determine the flow characteristics for any region, thousands of such equation representing the flow at every individual cell are written and by using finite differences technique the solution for these equations could be determined.

Many Numerical solutions techniques are available, some are forward solutions and others are backwards solutions while some of them are a combination of the two. The Numerical solution equations could be found at Rushton [2 ].

The assumptions for these equations to be valid are:

- The soil characteristics of a specific cell are homogeneous but differ from cell to cell.

- The water head is constant measured from cell center to its edge.

- The flow at any cell depends on Darcy equation.

- The flow equations are density independent.

\section{NUMERICAL MODEL AND SIMULATION}

Numerical model simulation system was used to build numerical model for study region. The finite-difference flow code (MODFLOW) existed within groundwater modeling system (GMS), [3], [4] was used to perform this simulation. Using this 
system, the study area was divided into large number of squares similar in size called cells. The water balance equation for each cell was applied after feeding the data available for some variables and assuming values for the others. The hydraulic head values designated by water elevations for all point in the study area could be estimated as a result from model operation , [5], [7].

The tools in Geographic information system (GIS) was used to build up the numerical model and to aid in the combination processes of topological, geological and hydrological data using curves, points and polygons which representing different features.

The study area (Mosul city) which is about $528 \mathrm{~km}^{2}$ as shown in fig (1) was implemented to apply the model. The region was divided into three dimension cells using 90 horizontal lines in the x-direction and 82 vertical lines in the y-direction result in a network with 7380 cells. The dimension for each cell is $(275 * 275)$ meter. The hydraulic conductivity Values ranged between (0.01 to 100$) \mathrm{m} /$ day was assumed to run the automated parameter estimation technique (PEST), [8] to obtain the elevations for groundwater in the study region as a result. The model was calibrated using actual data of water elevations measured from field. The calibration process continues to minimize the values of changes between the actual measured data with data results from model. After large number of trials, a best matching between the measured and the predicted values was obtained and the average difference for water depth is about $8 \mathrm{~cm}$ in all the study area as shown in figure (2) and table (2).

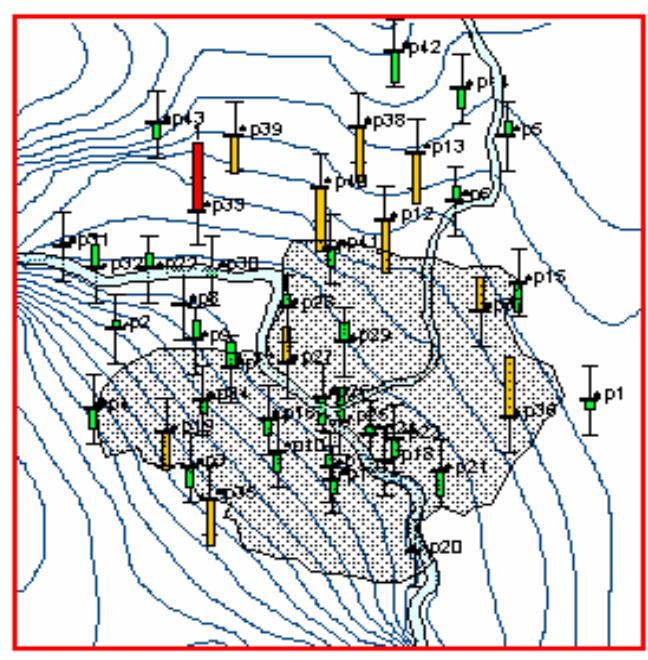

Figure 2a. Differences between computed and measured elevations by automated calibrations using PEST method (Feb. 2002)

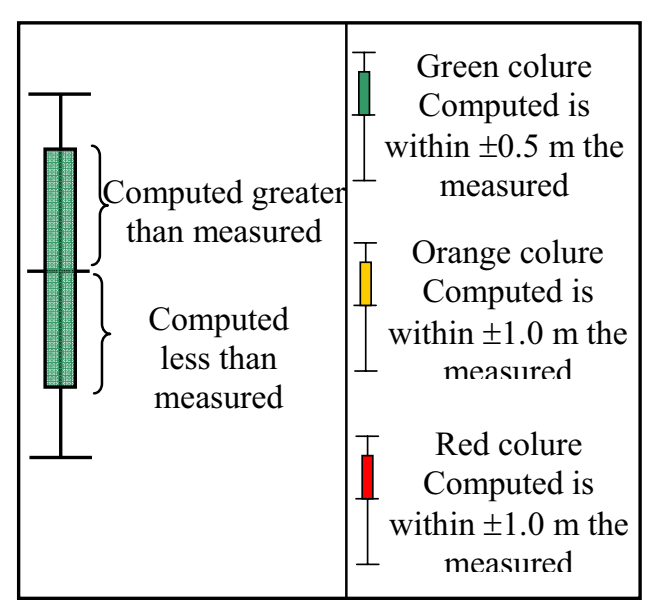

Figure 2b. Relationship between computed and measured elevation values. 
As a result from the numerical model operation the groundwater movement vectors within Mosul city were found as shown in figure (3). Through the identification of the vectors of the groundwater movements the feeding source of water for any point inside the study area was obtained. Knowing the source of water feeding for any region is very useful and could be used to stop and cut the source of water in case of increasing the groundwater elevations above undesired level. Figure (4) shows the critical zones within Mosul city concerning the elevations of groundwater to be near ground surface. The lands in critical zones are flooded with water during rainfall season with a very weak drainage through waste and storm water network. This is due to the unbalanced phenomenon occurs in the study area between the feeding water quantities to the groundwater ( rainfall, waste water and leakage water quantities from domestic water supply network) with the hydraulic conductivity of the soil $(\mathrm{K})$. Consequently, this will cause a reduction in the aquifer capability to store and transmit the excess water quantities to the river.

Table 2. Comparison between observed water elevations in shallow wells with the computed elevations resulting from numerical model.

\begin{tabular}{|c|c|c|c|c|c|c|c|c|c|c|c|}
\hline $\begin{array}{l}\text { Well } \\
\text { No. }\end{array}$ & $\begin{array}{c}\text { G.Elv. } \\
\text { (m.a.s.I) }\end{array}$ & $\begin{array}{c}\text { Observed } \\
\text { (m) }\end{array}$ & $\begin{array}{c}\text { Computed } \\
\text { (m) }\end{array}$ & $\begin{array}{c}\text { Residuals } \\
\text { (m) }\end{array}$ & $\begin{array}{c}\text { water } \\
\text { depth } \\
\text { (m) }\end{array}$ & $\begin{array}{l}\text { Well } \\
\text { No. }\end{array}$ & $\begin{array}{l}\text { G.Elv. } \\
\text { (m.a.s.l) }\end{array}$ & $\begin{array}{c}\text { Observed } \\
\text { (m) }\end{array}$ & $\begin{array}{c}\text { Computed } \\
\text { (m) }\end{array}$ & $\begin{array}{c}\text { Residuals } \\
\text { (m) }\end{array}$ & $\begin{array}{c}\text { water } \\
\text { depth } \\
\text { (m) }\end{array}$ \\
\hline p1 & 251.33 & 243.2 & 242.98 & -0.22 & 8.13 & P23 & 219.69 & 212.3 & 211.73 & -0.57 & 7.39 \\
\hline p2 & 245.08 & 234.1 & 34.35 & 0.25 & 10.98 & p24 & 213.5 & 210.05 & 210.29 & 0.24 & 3.45 \\
\hline p3 & 249.12 & 245.3 & 244.75 & -0.55 & 3.82 & p25 & 211.8 & 208.16 & 209.14 & 0.98 & 3.64 \\
\hline p4 & 272.78 & 262.4 & 261.83 & -0.57 & 10.38 & p26 & 213.5 & 210.22 & 209.44 & -0.78 & 3.28 \\
\hline p5 & 264.45 & 253.5 & 253.98 & 0.48 & 10.95 & p27 & 215.72 & 208.33 & 209.38 & 1.05 & 7.39 \\
\hline p6 & 253.32 & 242.32 & 242.76 & 0.44 & 11 & p28 & 218.33 & 210.15 & 210.52 & 0.37 & 8.18 \\
\hline p7 & 218.32 & 212 & & 0.78 & 6.29 & p29 & 219.03 & 215.2 & 8 & 0.6 & 3.83 \\
\hline p8 & 222.31 & 214.1 & 214.16 & 0.06 & 8.21 & p30 & 219.5 & 211.4 & 211.32 & -0.08 & 8.1 \\
\hline p9 & 223.12 & 217.72 & 218.33 & 0.61 & 5.4 & p31 & 225.37 & 218.08 & 218.23 & 0.15 & 7.29 \\
\hline p10 & 226.31 & 223.26 & 222.69 & -0.57 & 3.05 & p32 & 217.9 & 212.21 & 212.882 & 0.672 & 5.69 \\
\hline p11 & 220.45 & 215.4 & 215.02 & -0.38 & 5.05 & p33 & 228.87 & 222.12 & 226.64 & 4.52 & 6.75 \\
\hline p12 & 252.53 & 242.13 & 240.58 & -1.55 & 10.4 & p34 & 230.04 & 227.32 & 226.98 & -0.34 & 2.72 \\
\hline p13 & 261.62 & 254.5 & 253.01 & -1.49 & 7.12 & p35 & 252.12 & 248.16 & 246.84 & -1.32 & 3.96 \\
\hline p14 & 268.73 & 257.6 & 256.99 & -0.61 & 11.13 & p36 & 236.62 & 229.6 & 231.4 & 1.8 & 7.02 \\
\hline p15 & 255.14 & 245.2 & 244.39 & -0.81 & 9.94 & p37 & 244.74 & 236.24 & 237.25 & 1.01 & 8.5 \\
\hline p16 & 221.33 & 217.25 & 216.78 & -0.47 & 4.08 & p38 & 269.22 & 260.1 & 258.55 & -1.55 & 9.12 \\
\hline p17 & 217.36 & 212.8 & 213.15 & 0.35 & 4.56 & p39 & 255.88 & 248.35 & 247.25 & -1.1 & 7.53 \\
\hline p18 & 213.3 & 209.15 & 209.11 & -0.04 & 4.15 & p40 & 255.14 & 246.07 & 244.25 & -1.82 & 9.07 \\
\hline p19 & 251.86 & 244.6 & 243.54 & -1.06 & 7.26 & p41 & 240.05 & 234.11 & 233.58 & -0.53 & 5.94 \\
\hline p20 & 213.13 & 207.18 & 207.3 & 0.12 & 5.95 & p42 & 278.1 & 270.21 & 269.27 & -0.94 & \begin{tabular}{|l|}
7.89 \\
\end{tabular} \\
\hline p21 & 222.78 & 214.2 & 213.53 & -0.67 & 8.58 & p43 & 265.17 & 257.34 & 256.89 & -0.45 & 7.83 \\
\hline p22 & 218.57 & 211.5 & 211.99 & 0.49 & 7.07 & & & & & & \\
\hline
\end{tabular}

The ground water path lines of the study area were predicted from the model operation as shown in figure (5). This figure shows the paths of groundwater movements from the external area around Mosul city toward city centre especially 
toward Tigris River. Generally speaking, the operation of the present numerical model is used to obtain the sites having undesired groundwater elevations, as shallow groundwater depths have a negative influence on environment and health. Additionally it has negative effects on the foundations of engineering structures. Moreover, the filling of storm water network and prevention of discharging the rainfall quantities may lead to settlements and constructions subsidence.

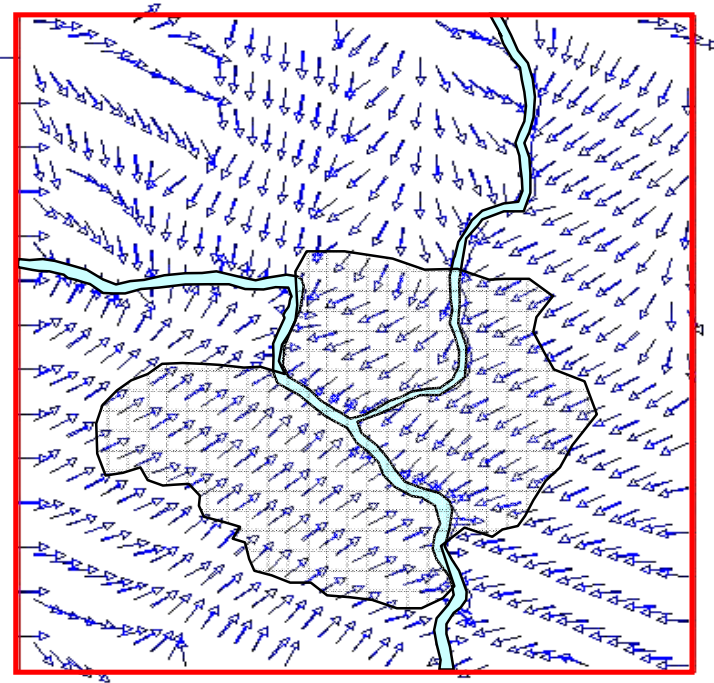

Figure 3. Flow vectors showing the groundwater flow directions (Feb. 2002).

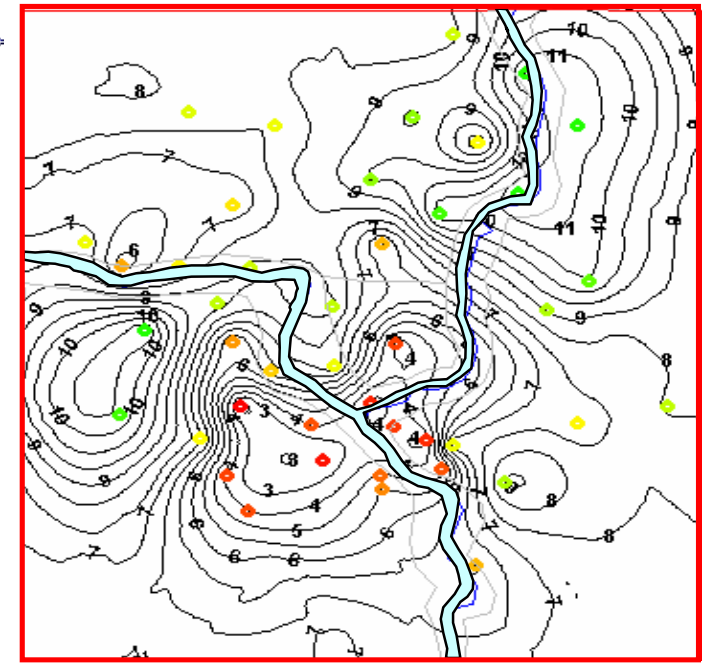

Figure 4. Contour lines for groundwater depths measured from ground surface.

Another result from model prediction are the values of hydraulic conductivity for the aquifers in the study area as shown in figure (6). The hydraulic conductivity values are found to range between (4 to 28) meter/day.

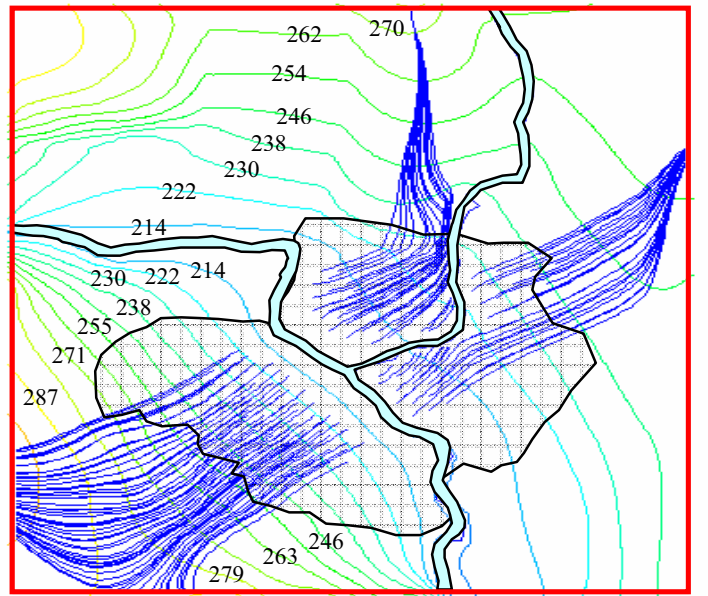

Figure 5. Groundwater flow lines feeding the critical regions in Mosul city.(Feb. 2002).

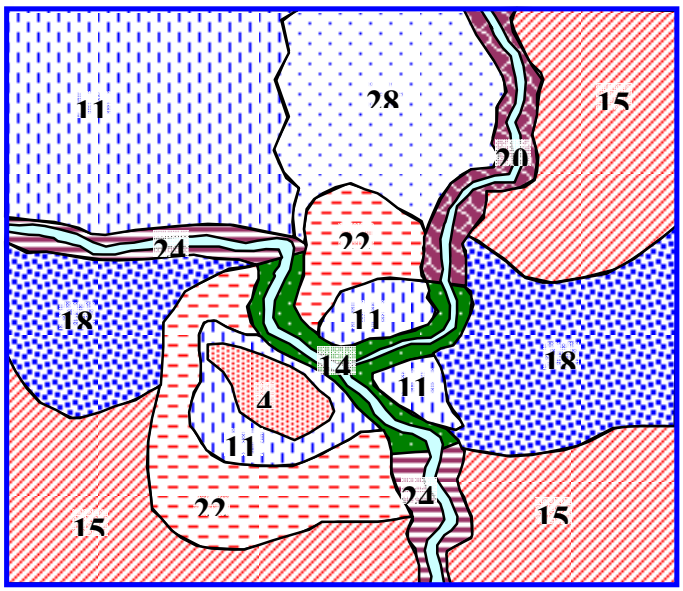

Figure 6. Hydraulic conductivity values in $\mathrm{m} /$ day for different zones in the study region according to the results from numerical model after final calibration. 


\section{CONCLUSIONS}

From the operation of the proposed numerical model, several conclusions concerning groundwater characteristics were found:

- Predicting the zones having undesired values of groundwater elevations due to its shallow depth.

- Predicting flow vectors which represents flow directions in each point.

- Predicting the groundwater paths leading to critical zones using flow lines.

The simulation process indicates that the actual reason behind the increasing in the groundwater elevations in Mosul city belong to the unbalance occurs in the study area through the increasing in the feeding sources to groundwater (water supply, sanitary drainage and rainfall) with the decrement in the hydraulic conductivity values $(\mathrm{k})$ as a result of the variation in the soil properties. Consequently this will reduce the capability of the aquifers to store or transmit the additional water quantities to the river and cause high groundwater elevations year after year.

\section{REFERENCES}

1. Research Centre for Dams and Water Resources Researches, Report on the evaluation of Groundwater Problem within Mosul City. (2000)

2. Rushton, K.R. and S.C. Redshaw (1979) Seepage and Groundwater Flow/ Numerical Analysis by Analog and Digital Methods. John Wiley \& Sons, New York, USA.

3. Harbaugh, A. W., and McDonald, M. G. "User's documentation for MODFLOW96, an update to the U.S. Geological Survey modular finite-difference groundwater flow model.' Open File Rep. 96-485, U.S. Geological Survey, Reston, Va. (1996).

4. ECGL Engineering Computer Graphics Laboratory, Groundwater Modeling System GMS 4, Reference Manual Brigham Young University,. Utah. USA. (2003)

5. Faust, C.R. and J.W. Mercer, Groundwater Modeling: Numerical Models. J. Groundwater, 18(4): 395-409. (1980)

6. Mercer, J.W. and C.R. Faust Groundwater Modeling: An Overview. $J$. Groundwater, 18(2): 108-115. (1980)

7. Thomas, R.G., Groundwater Models. FAO, Irrigation and Drainage Paper 21,Rome, Italy. (1973)

8. John Doherty, Model-Independent Parameter Estimation (PEST), Water marks numerical computing, Forth edition, (2000) 